Wijerathne, M.D.I.R., Gunasekara, K.A. and Perera, B.A.K.S., 2019. Overcoming the challenges of sustainable development in Sri Lanka using lean construction principles. In: Sandanayake, Y.G., Gunatilake, S. and Waidyasekara, A. (eds). Proceedings of the $8^{\text {th }}$ World Construction Symposium, Colombo, Sri Lanka, 8-10 November 2019, pp. 473-483. DOI: doi.org/10.31705/WCS.2019.47. Available at: https://2019.ciobwcs.com/papers

\title{
OVERCOMING THE CHALLENGES OF SUSTAINABLE DEVELOPMENT IN SRI LANKA USING LEAN CONSTRUCTION PRINCIPLES
}

\author{
M.D.I.R. Wijerathne ${ }^{1}$, K.A. Gunasekara ${ }^{2}$ and B.A.K.S. Perera ${ }^{3}$
}

\begin{abstract}
Sustainability is gaining popularity in the construction industry because of the growing concern that the industry has on the serious negative impacts of construction activities on the environment. To achieve sustainable development through environmentally friendly practices, such as green building practices, construction waste management would be essential. However, the new construction philosophy lean, can be used to overcome the environmental challenges of sustainable development. Thus, the aim of this study was to investigate how the challenges of sustainable development could be overcome in Sri Lanka using the principles of lean construction. The study used a qualitative approach consisting of a literature review and 20 expert interviews. Interview findings were analyzed manually using content analysis. Specifying value and identifying the value stream were found to be the most suitable lean principles that can overcome the challenges of sustainable development. The research findings also reveal that there is an urgent requirement to practice lean principles in the construction industry in Sri Lanka.
\end{abstract}

Keywords: Lean Construction Principles; Sustainability Challenges; Sustainable Development.

\section{INTRODUCTION}

Sustainability enables the satisfaction of the needs of the current population to fulfil the needs of the future generations without any risks while protecting the environment (Wao et al., 2016). The move towards sustainability is a modern paradigm (Vanegas et al., 1996). By considering sustainable principles, significant value can be obtained, especially in the built environment (Andelina et al., 2015). Population growth; urbanization; global warming; high energy usage; high levels of soil, air and water pollution; fast waste generation; transportation; resource constraints etc., have to be considered when undertaking sustainable development (De Sherbinin et al., 2007).

During the past several decades, the quantity of waste produced during construction has increased considerably (Formoso et al., 2002). To monitor waste disposal, a wide range

\footnotetext{
${ }^{1}$ Department of Quantity Surveying, Sri Lankan Institute of Information Technology, Sri Lanka, ishararavihari95@gmail.com

${ }^{2}$ Department of Quantity Surveying, University of Vocational Technology, Sri Lanka, kasunamali@yahoo.com

${ }^{3}$ Department of Building Economics, University of Moratuwa, Sri Lanka, kanchana@uom.lk
} 
of measures, including the control of excess consumption of materials, have already been adopted (Formoso et al., 2002). For the sustainable development in the construction industry, the use of green building practices is essential to manage construction waste (Kamar et al., 2010).

To achieve sustainable development, construction industry also has to change its processes from linear to cyclic processes, increase the use of reused, renewed and recycled resources and decrease the consumption of energy and natural resources (Miyatake, 1996).

Koskela (1992), an inventor, introduced a new construction philosophy known as lean, to address the environmental issues faced by the construction industry in pursuing sustainable development. Lean principles provide gargantuan possibilities to improve the industry and help to solve industrial problems (Hallman, 2013). Lean construction principles are also believed to improve the construction industry as a whole (Egan, 1998; Howell and Ballard, 1998). Some argue that because of the specific characteristics of construction, lean principles as they are may not be applicable to the construction sector (Winch, 2003). Many researchers, however, have focused their attention on the lean construction concept, which is expected to minimize the waste in the construction industry (Lim, 2008; Lean Construction Institute, 2012). According to the Lean Construction Institute (2012), lean construction focuses on minimizing wastage using unique techniques, thereby enhancing the value of production. Hence, the main aim of lean construction can be considered as the development of the construction process by reducing the waste generated in construction while maximizing the value of the project. If as claimed by the Lean Construction Institute (2012), lean construction can maximize the value of a construction project, it will lead to cost savings, high quality end products and increased confidence in the safety and project sustainability on the part of construction laborers. According to Green and May (2005), lean is a socio-technical concept, valuable to the work culture of an organization. Therefore, it is important to study the interconnection between the sustainable challenges and lean concept. The aim of this research was, therefore, to identify the contribution made by lean construction principles towards meeting the challenges of sustainable development in Sri Lanka. The objectives of the research were to identify the principles of lean construction and the significant challenges of sustainable development, and the use of lean construction principles to overcome the identified challenges. While cost, performance and quality are the criteria traditionally used to assess building materials, products and systems, sustainability criteria relate to resource depletion, environmental degradation and a healthy environment (Kibert, 1994).

\section{RESEARCH PROBLEM}

Construction industry is a large-scale waste producer, which impacts heavily on the environment because of the large quantities of natural resources it consumes (Wu et al., 2014). Therefore, it needs to focus on sustainable construction. One possible approach to sustainable construction can be lean construction as it focuses on introducing social and environmental issues as new values to be achieved rather than on its mere accidental benefits to the environment (Nahmens and Ikuma, 2011). There is a research gap on the contribution made by lean construction principles to overcome the challenges of sustainable development in the construction sector of developing countries like Sri Lanka. 
This subject, however, has already been studied in the context of developed countries like UK.

\subsection{Lean CONCEPT AND LEAN PRINCIPLES}

Rachman and Ratnayake (2018) described the lean concept as an approach for performing activities more efficiently, i.e. with fewer resources (e.g. time, workforce, equipment and space). The lean concept has also been argued as a methodology that could enhance the business performance of the petroleum industry (Banawi et al., 2014). The basic concept behind lean is the elimination of waste. To eliminate waste, production systems in construction have to be designed to reduce the waste of resources, time, and effort and maximise the values (Arashpour and Arashpour, 2015). The lean concept essentially includes the development of a clear set of objectives for the delivery process of a project and the application of project control throughout the life cycle of the project, i.e., from its design to delivery (Meng, 2019). In the construction industry, the lean concept advocates the concurrent consideration of the development of production as well as construction process. Lean theory can be categorized into five principles (Aziz and Hafez, 2013) as summarized in Table 1.

Table 1: Categories of lean principles

\begin{tabular}{ll}
\hline \multicolumn{1}{c}{ Principle } & \multicolumn{1}{c}{ How it is performed } \\
\hline Specifying value to the customer & $\begin{array}{l}\text { By identifying the value of related activities to ensure } \\
\text { the value of the final product } \\
\text { By eliminating waste to remove all activities that will } \\
\text { not add value to the final product } \\
\text { Identifying the value stream }\end{array}$ \\
$\begin{array}{ll}\text { Making a continuous improvement } \\
\text { Ealue chain and the process } \\
\text { the agreed time duration }\end{array}$ \\
$\begin{array}{l}\text { Having pull driven systems } \\
\text { By monitoring the whole supply chain }\end{array}$ \\
\hline
\end{tabular}

There are eleven lean principles (Koskela, 1992): minimizing the share of non- value adding activities, increasing the output value through the proper consideration of the customer needs, reducing the variability, reducing the cycle times, simplifying by reducing the number of steps, parts and linkages, increasing the output elasticity, increasing the process transparency, focus controlling the complete process, building continuous improvement into the process, balancing the flow improvement with conversion improvement, and benchmarking.

\subsection{NEED FOR LEAN CONSTRUCTION}

A key part of the lean project delivery process is the elimination and reduction of waste, i.e., non-value adding activities (Abdelhamid and Salem, 2005). According to Thilakarathna and Senarathne (2012), in Sri Lanka, which is still a developing country, non-value adding activities (NVAA) are at a significant level of which most significant are the "defects" and "waiting". By eliminating waste, lean construction assures the results of a construction project by managing its construction process and accomplishing its goals (Jamil and Fathi, 2016). 
Construction industry, which lacks efficiency, faces numerous difficulties. Therefore, the industry can use lean construction to overcome a majority of its problems (Alinaitwe, 2009). In human resource management, the lean concept gives employees the opportunity to make informed choices about their workplace performance, nature of their contribution, resolution of self-issues and their job satisfaction (Wickramasinghe and Wickramasinghe, 2012). Furthermore, it enables the workers to enjoy enriched jobs, with autonomy to make decisions (Howell, 1999).

\subsection{MAJOR CHALLENGES OF SUSTAINABILITY}

The concept of sustainability originated during early human civilizations, such as South African Bushmen (Ding, 2008). Since then the concept has been adopted by many industries and today the society is encouraged to embrace sustainability in order to create a better world (Shen et al., 2011). Sustainable development is interrelated to economic growth and environment (Ding, 2008). In the construction industry, high performance and green / sustainable construction are often interchangeable. Yet, sustainable construction is most popular with regard to ecological, social, and economic problems of a building (Ding, 2008). To ensure sustainability, a "beneficial co-existence" is required to generate and sustain the environmental, social and economic conditions that allow people to live with nature, today as well as in the future. In the construction industry, sustainable objectives are considered at each stage of the building lifecycle. These sustainable objectives are often an encumbrance to the environment. However, it will not be possible to resolve environmental issues if poverty remains (Hart, 1997). The challenges faced by the different economic sectors of a country with regard to sustainability can be different. These challenges as identified by Hart (1997) are presented in Table 2.

Table 2: Major challenges to sustainability

\begin{tabular}{|c|c|c|c|}
\hline & Developed economies & Emerging economies & Survival economies \\
\hline Pollution & $\begin{array}{l}\text { Greenhouse gases, } \\
\text { toxic materials, } \\
\text { polluted sites }\end{array}$ & $\begin{array}{l}\text { Industrial emissions, } \\
\text { polluted water, } \\
\text { lack of sewage treatment }\end{array}$ & $\begin{array}{l}\text { Dung and wood burning, } \\
\text { lack of sanitation, } \\
\text { ecosystem destruction } \\
\text { due to development }\end{array}$ \\
\hline Depletion & $\begin{array}{l}\text { Material scarcity, } \\
\text { insufficient reuse and } \\
\text { recycling of the } \\
\text { materials }\end{array}$ & $\begin{array}{l}\text { Overuse of renewable } \\
\text { resources, overuse of } \\
\text { water for irrigation }\end{array}$ & $\begin{array}{l}\text { Deforestation, } \\
\text { overgrazing, soil loss }\end{array}$ \\
\hline Poverty & $\begin{array}{l}\text { Urban and minority } \\
\text { unemployment }\end{array}$ & $\begin{array}{l}\text { Urbanization, } \\
\text { lack of skilled workers, } \\
\text { income differences }\end{array}$ & $\begin{array}{l}\text { Population growth, } \\
\text { low status of women, } \\
\text { dislocation }\end{array}$ \\
\hline
\end{tabular}

\subsection{NEED FOR LEAN PRINCIPLES TO OVERCOME THE BARRIERS AND Challenges of Sustainable CONSTRUCtion}

Institutional sustainability will be significant for an organization to achieve competitive success (Porter and Kramer 2006). However, the reason for maintaining institutional sustainability is usually based more on legal requirements, while cost of running a business is considered as a necessary evil to maintain legitimacy (Hart and Milstein, 2003). The main reason for applying lean in an organization is often an adverse incentive, 
such as a financial disaster (Womack and Jones, 1996). One main topic that is discussed even amidst environmental disasters is the integration of environmental, social and economic goals (Hargroves and Smith, 2005). Thus, it is important to disclose the positive side of sustainability when introducing lean management to businesses.

\section{RESEARCH METHODOLOGY}

The research question of this study was 'How to meet the challenges of sustainable development in Sri Lanka using the principles of lean construction'. According to Yin (2009), a research question starting with the word 'how' is more explanatory in nature and requires tracing operational links in a phenomenon which otherwise would not be achievable by depending only on frequencies. By using a qualitative approach in a research, the exploration and a better understanding of the complexity of a phenomenon will be possible (Williams, 2007). Thus, this research used a qualitative approach, which contained 15 semi structured interviews (using an interview guideline) conducted with professional experts, each of whom had more than 5 years of experience in working in the construction industry in the Western Province of Sri Lanka. Each of the face to face interviews lasted for 45-60 minutes. The data collected were analysed using manual content analysis.

\section{RESEARCH FINDINGS}

\subsection{IDENTIFICATION OF THE CHALLENGES OF SUSTAINABLE DEVELOPMENT AND THE LEAN PRINCIPLES TO OVERCOME THEM}

The challenges of sustainable development identified using the literature review was validated in the Sri Lankan context through the interviews. The interviewees were requested to remove, add to and modify the challenges identified from the literature to suit Sri Lanka. They were also requested to validate the lean principles identified from the literature by adding to, removing or changing them, based on their experience. They were thereafter requested to identify the lean principles that are suitable for overcoming the challenges of developing the three categories of sustainability: economic, environmental and social sustainability. They were also requested to describe the application of the lean principles to overcome each challenge.

\subsection{Lean Principles that Will OVERCome The Challenges OF DEVELOPING ECONOMIC SUSTAINABILITY}

The challenges of developing economic sustainability and their associated lean principles identified from the literature and validated through the interviews are summarised in Table 3.

Table 3: Lean principles that will overcome the challenges of developing economic sustainability

\begin{tabular}{lll}
\hline \multicolumn{3}{c}{ Challenges for economic } \\
sustainability
\end{tabular}




\begin{tabular}{|c|c|c|}
\hline & $\begin{array}{l}\text { Challenges for economic } \\
\text { sustainability }\end{array}$ & Lean principles \\
\hline 3 & $\begin{array}{l}\text { Poor workmanship during } \\
\text { construction }\end{array}$ & $\begin{array}{l}\text { Continuous flow, Perfection, Pull driven system, } \\
\text { Specifying value }\end{array}$ \\
\hline 4 & $\begin{array}{l}\text { Mode of funding the project / } \\
\text { Financing the project }\end{array}$ & $\begin{array}{l}\text { Identifying the value stream, Perfection, Specifying } \\
\text { value, Pull driven system }\end{array}$ \\
\hline 5 & Unrealistic project duration & $\begin{array}{l}\text { Continuous flow, Pull driven system, Identifying the } \\
\text { value stream }\end{array}$ \\
\hline 6 & Budget constraints & $\begin{array}{l}\text { Specifying value, Identifying the value stream, } \\
\text { Continuous flow }\end{array}$ \\
\hline 7 & $\begin{array}{l}\text { Lack of technical expertise in } \\
\text { sustainable construction }\end{array}$ & $\begin{array}{l}\text { Identifying the value stream, Perfection, Continuous } \\
\text { flow }\end{array}$ \\
\hline 8 & Greenhouse gases & $\begin{array}{l}\text { Identifying the value stream, Perfection, Specifying } \\
\text { value }\end{array}$ \\
\hline 9 & Migration to cities & Perfection, Pull driven system, Specifying value \\
\hline 10 & Lack of skilled workers & $\begin{array}{l}\text { Specifying value, Identifying the value stream, Pull } \\
\text { driven system }\end{array}$ \\
\hline 11 & Income inequality & Perfection, Pull driven system, Continuous flow \\
\hline 12 & Population growth & $\begin{array}{l}\text { Identifying the value stream, Perfection, Specifying } \\
\text { value }\end{array}$ \\
\hline
\end{tabular}

Several new lean principles were also identified by the interviewees: reducing the share of non-value adding activities, increasing the output value through systematically considering customer requirements, reducing variability and reducing cycle time. The interviewees also identified several new challenges of developing economic sustainability, such as payment problems faced in the construction industry, insufficient knowledge of project managers, low number of progress meetings, lack of equipment and machinery, financial issues and lack of competent people to implement the systems.

\subsection{Lean Principles that CAN OVERCome the Challenges of ENVIRONMENTAL SUSTAINABILITY}

The challenges of developing environmental sustainability and the lean principles applicable to them that were identified from the literature and validated through the interviews are summarized in Table 4.

Table 4: Lean principles that will overcome the challenges of developing environmental sustainability

\begin{tabular}{lll}
\hline \multicolumn{1}{c}{$\begin{array}{c}\text { Challenges of environmental } \\
\text { sustainability }\end{array}$} & \multicolumn{1}{c}{ Lean principles } \\
\hline 1 & $\begin{array}{l}\text { Lack of knowledge and non- } \\
\text { availability of alternative sustainable } \\
\text { materials }\end{array}$ & $\begin{array}{l}\text { Identifying the value stream, Specifying value, } \\
\text { Continuous flow }\end{array}$ \\
$2 \quad \begin{array}{l}\text { Poor working conditions in relation } \\
\text { to safety }\end{array}$ & $\begin{array}{l}\text { Pull driven system, Identifying the value stream, } \\
\text { Continuous flow } \\
\text { Identifying the value stream, Pull driven system, } \\
\text { Coor construction methods }\end{array}$ & $\begin{array}{l}\text { Continuous flow } \\
\end{array}$
\end{tabular}




\section{Challenges of environmental} sustainability

4 Lack of demand for sustainability in construction from the clients

5 Use of toxic materials

6 Contaminated sites

7 Industrial emissions

8 Contaminated water/ Contaminated water at the site

9 Dung and wood burning/ Increased pollution

10 Ecosystem destruction caused by development

11 Insufficient reuse and recycling of resources

12 Over exploitation of renewable resources

13 Deforestation

14 Overgrazing

15 Soil loss

\section{Lean principles}

Specifying value, Perfection, Identifying the value stream

Specifying value, Perfection, Identifying the value stream

Specifying value, Identifying the value stream, Perfection

Specifying value, Identifying the value stream, Perfection

Identifying the value stream, Perfection, Specifying value

Specifying value, Identifying the value stream, Perfection

Pull driven system, Perfection, Specifying value

Specifying value, Identifying the value stream, Perfection

Perfection, Identifying the value stream, Pull driven system

Identifying the value stream, Pull driven system, Perfection

Specifying value, Identifying the value stream, Perfection

Identifying the value stream, Pull driven system, Specifying value

The interviewees identified several new challenges of developing environmental sustainability, such as educating clients on sustainability methods and requesting them to implement them, failure to work closely with environmental authorities towards getting the approvals and absence of a proper market for sustainable operations.

\subsection{LeAN PRINCIPLES THAT CAN OVERCOME THE CHALLENGES OF DEVELOPING SOCIAL SUSTAINABILITY}

The challenges of developing social sustainability and the associated lean principles identified from the literature and validated through the interviews are summarised in Table 5.

Table 5: Lean principles that will overcome the challenges of developing social sustainability

\begin{tabular}{lll}
\hline & Challenges for social sustainability & \multicolumn{1}{c}{ Lean principles } \\
\hline 1 & $\begin{array}{l}\text { Inadequate awareness and knowledge } \\
\text { of the concept of sustainability and its } \\
\text { benefits }\end{array}$ & Specifying value, Perfection, Continuous flow \\
2 & $\begin{array}{l}\text { Poor understanding of project } \\
\text { objectives and requirements. }\end{array}$ & $\begin{array}{l}\text { Specifying value, Continuous flow, Pull driven } \\
\text { system }\end{array}$
\end{tabular}




\begin{tabular}{|c|c|c|}
\hline & Challenges for social sustainability & Lean principles \\
\hline 3 & $\begin{array}{l}\text { Lack of related legislation and } \\
\text { government support }\end{array}$ & $\begin{array}{l}\text { Specifying value, Continuous flow, Pull driven } \\
\text { system }\end{array}$ \\
\hline 4 & $\begin{array}{l}\text { Incompetence of } \\
\text { contractors/subcontractors }\end{array}$ & $\begin{array}{l}\text { Pull driven system, Continuous flow, Specifying } \\
\text { value }\end{array}$ \\
\hline 5 & $\begin{array}{l}\text { Unwillingness to adopt new } \\
\text { construction methods }\end{array}$ & $\begin{array}{l}\text { Specifying value, Identifying the value stream, } \\
\text { Continuous flow, Pull driven system, Perfection }\end{array}$ \\
\hline 6 & $\begin{array}{l}\text { Economic, physical and social } \\
\text { environment of the educational } \\
\text { building project }\end{array}$ & Pull driven system, Perfection, Specifying value \\
\hline 7 & Non availability of sewage treatment & $\begin{array}{l}\text { Identifying the value stream, Perfection, } \\
\text { Continuous flow, Specifying value, Pull driven } \\
\text { system }\end{array}$ \\
\hline 8 & Absence of sanitation & Continuous flow, Pull driven system, Perfection \\
\hline 9 & Scarcity of materials & $\begin{array}{l}\text { Identifying the value stream, Perfection, } \\
\text { Specifying value }\end{array}$ \\
\hline 10 & Overuse of water for irrigation & $\begin{array}{l}\text { Identifying the value stream, Pull driven system, } \\
\text { Perfection }\end{array}$ \\
\hline 11 & Urban and minority unemployment & $\begin{array}{l}\text { Pull driven system, Specifying value, Identifying } \\
\text { the value stream }\end{array}$ \\
\hline 12 & Low status of women & $\begin{array}{l}\text { Perfection, Specifying value, Identifying the } \\
\text { value stream }\end{array}$ \\
\hline
\end{tabular}

Some of the challenges faced in developing social sustainability, such as the nonavailability of continuing professional development (CPD) programs for new graduates; little attention paid to the implementation of sustainable practices; non-availability of a proper market place for sustainable operations; education systems and cultural gaps; top management's perception of sustainability as being costly; conflicts with the government and organizational policies; and rules and regulations were identified through the interviews.

There are many ways of applying these lean principles to overcome the challenges of attaining sustainability identified through the interviews. The lean principles common to all three types of sustainability are imparting knowledge about the lean principles, educating the relevant personnel about sustainability, training of the relevant personnel, standardization of sustainable construction practices, government and foreign funding, realistic construction periods, accurate preliminary estimates, new R\&D methods, green buildings, professional education systems, use of alternative methods, HSE (health, safety and environment) toolbox workshops and lean based safety applications, reviewing of the construction methodology to be used before commencing construction, legal enforcement through the state sector, adherence to ISO (International Organization for Standardization) standards, making clients aware about green-house education, life cycle analysis over construction and pre-qualifying the contractors based on CIDA (Construction Industry Development Authority) categorizations.

The research findings indicate that the lack of or inadequate knowledge of sustainability is a challenge common to all three types of sustainability. To overcome these challenges, practices such as conducting discussions to enlighten the relevant personnel about the 
related issues, educating all employees about issues related to sustainability and providing lean based higher education systems to the relevant professionals, conducting training and awareness programs to all employees, and explaining to the customers the benefits of sustainability can be adopted. Moreover, poor workmanship during construction, lack of technical expertise in sustainable construction, poor construction methods and the incompetence of contractors/subcontractors can be identified as the workmanship related challenges of economic, environmental and social sustainability. These challenges can be overcome by applying practices such as employing a qualified quality engineer, introducing lean practices to all employees, standardizing sustainable construction practices, developing training programs, educating clients on sustainability methods, providing education on sustainability, providing lean based education, reviewing construction methodology by the engineer or architect before commencing construction, introducing sustainability development to construction, providing lean/sustainable based professional development on construction, using easy construction methods, prequalifying contractors based on CIDA guidelines, standardizing the lean construction practices used by the contractors and standardizing the contractors based on the lean and sustainable practices they use.

\section{CONCLUSIONS AND RECOMMENDATIONS}

Lean construction is a continuous process of overcoming the challenges faced in attaining sustainability, which establishes value for the end-product in construction. Though the concept originated in the production sector, many researchers all over the world have proved its applicability to the construction industry. Although there are different interpretations of the lean principles, all of them are mainly based on five common principles. The study enabled to identify the lean principles that can overcome the challenges faced in developing economic, environment and social sustainability in Sri Lanka thereby achieving the aim of the research. In addition to the lean principles and challenges of sustainable development already mentioned in the literature, several new lean principles and challenges were identified from the interviews. There is an urgent need to use lean principles in construction projects in Sri Lanka. Moreover, although many professionals have heard about lean construction, they know very little about it.

This study covered several aspects of using lean principles in Sri Lanka to overcome the challenges of sustainable development. The following recommendations will help to implement lean construction principles within the Sri Lankan organizations to facilitate the attainment of sustainability by overcoming any challenges present.

- Educating all stakeholders in the construction industry about lean principles and getting them to practice the principles in their respective organizations

- Standardizing contractors and clients based on their use of lean principles for sustainable development

\section{REFERENCES}

Abdelhamid, T. and Salem, S., 2005. December. Lean construction: a new paradigm for managing construction projects. In Proceedings of the International Workshop on Innovations in Materials and Design of Civil Infrastructure (pp. 28-29).

Alinaitwe, H. M., 2009. Prioritising Lean construction barriers in Uganda's construction industry. Journal of Construction in Developing Countries, 14(1), pp.15-30. 
Andelin, M., Karhu, J., and Junnila, S., 2015. Creating shared value in a construction project-a case study. Procedia Economics and Finance, 21, pp.446-453.

Arashpour, M. and Arashpour, M., 2015. Analysis of workflow variability and its impacts on productivity and performance in construction of multistory buildings. Journal of Management in Engineering, 31(6), p.04015006.

Aziz, R. F. and Hafez, S. M., 2013. Applying lean thinking in construction and performance improvement. Alexandria Engineering Journal, 52(4), pp.679-695.

Banawi, A. and Bilec, M.M., 2014. A framework to improve construction processes: Integrating Lean, Green and Six Sigma. International Journal of Construction Management, 14(1), pp.45-55

Ding, G.K., 2008. Sustainable construction-The role of environmental assessment tools. Journal of Environmental Management, 86(3), pp.451-464.

De Sherbinin, A., Schiller, A., and Pulsipher, A., 2007. The vulnerability of global cities to climate hazards. Environment and Urbanization, 19(1), pp.39-64.

Egan, J., (1998). Rethinking Construction: Report of the Construction Task Force. London: HMSO.

Formoso, C.T., Soibelman, L., De Cesare, C. and Isatto, E.L., 2002. Material waste in building industry: main causes and prevention. Journal of Construction Engineering and Management, 128(4), pp.316325.

Green, S. D. and May, S.S., 2005. Lean Construction: Arenas of Enactment, Models of Diffusion and the Meaning of 'Leanness'. Building Research and Information, 33(6), pp.498-511.

Hallman, M., 2013. Implementing last planner on construction sites (Doctoral dissertation, Chalmers University).

Hargroves, K. and Smith, M.H., 2005. Natural advantage of nations. Earthscan.

Hart, S.L., 1997. Beyond greening: strategies for a sustainable world. Harvard business review, 75(1), pp.66-77.

Hart, S.L. and Milstein, M.B., 2003. Creating sustainable value. Academy of Management Perspectives, 17(2), pp.56-67.

Howell, G.A., 1999, July. What is lean construction-1999. In Proceedings IGLC (Vol. 7, p. 1).

Howell, G. and Ballard, G., 1998. Implementing lean construction: understanding and action. In Proceedings of the $6^{\text {th }}$ Annual Conference of International Group for Lean Construction.

Jamil, A. H., and Fathi, M. S., 2016. The Integration of Lean Construction and Sustainable Construction: A Stakeholder Perspective in Analyzing Sustainable Lean Construction Strategies in Malaysia. Procedia Computer Science, 100, pp.634-643.

Kamar, K.A.M., Hamid, Z.A., Ghani, M.K., Egbu, C. and Arif, M., 2010. Collaboration initiative on green construction and sustainability through industrialized buildings systems (IBS) in the Malaysian construction industry. International Journal of Sustainable Construction Engineering and Technology, 1(1), pp.119-127.

Kibert, C.J., 1994, November. Establishing principles and a model for sustainable construction, Proceedings of the first international conference on sustainable construction (pp. 6-9). Tampa Florida, November.

Koskela, L., 1992. Application of the new production philosophy to construction. California: Stanford University.

Lean Construction Institute, 2012. What is lean construction?. [Online]. Available from: http://www.leanconstruction.org [Accessed 14 January 2018].

Lim, V.A.J., 2008. Lean construction: knowledge and barriers in implementing into Malaysia construction industry (Doctoral dissertation, Universiti Teknologi Malaysia)

Meng, X., 2019. Lean management in the context of construction supply chains, International Journal of Production Research, pp.1-13.

Miyatake, Y., 1996. Technology development and sustainable construction, Journal of Management in Engineering, 12(4), pp.23-27.

Nahmens, I. and Ikuma, L. H., 2011. Effects of lean construction on sustainability of modular homebuilding, Journal of Architectural Engineering, 18(2), pp.155-163. 
Porter, M.E. and Kramer, M.R., 2006. The link between competitive advantage and corporate social responsibility. Harvard Business Review, 84(12), pp.78-92.

Rachman, A., and Ratnayake, R. C., 2018. Social Network Analysis in Lean Thinking: A Method for Improving Information Flow in Technical Integrity Management System Development. In 2018 IEEE IEEM (pp. 1293-1298).

Shen, L. Y., Ochoa, J. J., Shah, M. N., and Zhang, X., 2011. The application of urban sustainability indicators-A comparison between various practices. Habitat International, 35(1), pp.17-29.

Thilakarathne, N. and Senarathne, S., 2012. Literature review on lean implementation cases in the construction process. In: FARU International Research Symposium, Sri Lanka, University of Moratuwa, pp.147-162.

Vanegas, J. A., DuBose, J. R., and Pearce, A. R., 1995. Sustainable technologies for the building construction industry. In: Symposium on Design for the Global Environment, Atlanta, GA. November (pp. 2-3).

Wao, J. O., Ries, R., Flood, I., and Kibert, C., 2016. Refocusing value engineering for sustainable construction. In: 52 ${ }^{\text {nd }}$ ASC Annual International Conference Proceedings (pp. 13-16).

Wickramasinghe, D. and Wickramasinghe, V., 2012. Effects of perceived organisational support on participation in decision making, affective commitment and job satisfaction in lean production in Sri Lanka, Journal of Manufacturing Technology Management, 23(2), pp.157-177.

Williams, C., 2007. Research methods. Journal of Business and Economic Research, 5(3), pp.65-72.

Winch, G., 2003. Models of manufacturing and the construction process: the genesis of re-engineering construction. Building Research and Information, 31(2), pp.107-118.

Womack, J. P. and Jones, D. T., 1996. Lean Thinking, Simon \& Schuster, New York.

Wu, Z., Ann, T. W., Shen, L., and Liu, G., 2014. Quantifying construction and demolition waste: An analytical review. Waste Management, 34(9), pp.1683-1692.

Yin, R.K., 2009. Case Study Research: Design and Methods, $4^{\text {th }}$ edn, Sage Publications, Thousand Oaks, California. 